\title{
'Behind you!'
}

\section{S. Hancocks, OBE*}

\author{
Every year at Christmas time happy panto folk aim to please \\ With humour, mirth and entertainment to delight and tease \\ But as the festive season passes, foul, wonderful or fair \\ In the intervening year, who maintains their oral care?
}

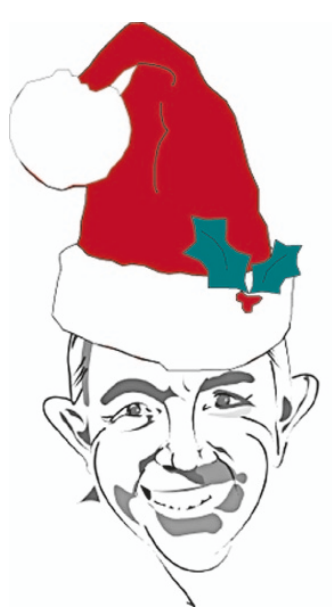

Referrals to veterinary colleagues were a routine matter, geese, ponies and cows being the most regular, and no more so than in the case of Dick Whittington's cat, whose build-up of calculus was legendary. Unfortunately a current dispute with Dick's private patients plan meant that the cat's refund was under question but, since the head office of the insurers was situated in the City, it would be a simple matter for Dick to call in and bang the desk the very next time he turned again to be Lord Mayor of London.

Just as on so many occasions the last patient of the day was late. Plus, it was, of
Generally though it was the work-a-day lot of an average GDP, well, perhaps not entirely average.

Drying himself off once inside the relative safety of his surgery, Colin heard large feet plonking into the reception accompanied by a huge laugh and a 'got you again I see' call of glee from their owner, Mischievous Mikey, one half of the cheeky Broker's Men duo. 'Very droll,' returned Colin from the depths of his towel, 'and where's your other partner in crime today?' looking nervously around for Pep-up Pete. 'He's had to take Dobbin to the blacksmith for a new set of horseshoes, I'll make another appointment for him next week,' grinned Mikey. Colin wasn't too sure he believed this but smiled just the same. They usually came in as a pair asking for their gold inlays to be taken out at times of financial hardship, and then reinserted once they had done a 'bit of business' and retrieved from the pawnshop. Colin never liked to ask the details and since they always paid in cash, and on the nail, he thought it best not to enquire further. Although he did think of writing it up for the PDJ (Panto Dental Journal) as a joint case report on one of the disadvantages of using posterior composites.

After Mikey had left, long range squirter in hand, it panned out to be a fairly normal sort of morning. The two Ugly Sisters, Kiss-

Me-Quick-Kate and Nip-and-Tuck-Naomi, were in for their monthly scale and polish, bad breath advisory session and, as it also a booster dose of botox in all four cheeks. They made a follow-up appointment for to get in extra-strength hydrogen peroxide for the event) and were ushered out by the receptionist with just minutes to spare before Cinderella arrived. There had been mayhem on a previous occasion when they all found themselves in the waiting room together and although it was usually possible to book them on different days, Cinders

\section{...right on time a large pumpkin pulled by six white mice manoeuvred itself neatly in the practice car park.}

had called up that morning as an emergency. Sure enough, right on time a large pumpkin pulled by six white mice manoeuvred itself neatly in the practice car park. Her Maryland Bridge needed re-cementing following a fall in the usual rush away from the palace at midnight. Anterior trauma being something of an occupational hazard where glass slippers and Prince Charming's balls were concerned.

After lunch Jack was in to have his orthodontic appliance adjusted. Although in the mixed dentition phase he'd been started on functional treatment as it was thought the constant exercise of climbing up and down the beanstalk might also harness the facial muscles to help expand the upper arch. He was in good spirits, clutching a whole box full of golden eggs which he was off to exchange for a necklace he wanted to give to his latest girlfriend, the lovely Princess Arveen. Colin couldn't help feel that the values of today's youth were being corrupted by fame at too early an age. course a prosthetics case. Widow Twanky burst in with a flurry of apologies, a brand new dress of blue gingham and two giant earrings made of old lightbulbs. 'I'm so sorry to be late,' she blustered, 'but that silly boy Wishee Washee forgot to remind me.' From reception a small reedy voice was heard to shout 'oh no I didn't'. The Widow was instantly on her guard. 'Oh yes you did,' she shouted back. 'Oh no I didn't,' came the inevitable riposte, and so it might have gone on had not Jane the dental nurse interrupted just in time. 'Where did you leave your dentures?' she asked. 'Why, in the pot on the side over there,' the Dame indicated with her large handbag made of several carpet tiles and a dishcloth. 'But where exactly?' Jane knew precisely what she was doing such an experienced nurse. 'Well look, girl, there, in the pot ... behind you!'

Happy yuletide to you all!

*Stephen Hancocks is Editor-in-Chief of the BDJ 